\title{
Incidental finding of a Sertoli-Leydig cell tumor in a postmenopausal woman with complex endometrial hyperplasia
}

\author{
Yeejeong Kim¹, In Ok Lee ${ }^{2}$, Jae Eun Chung ${ }^{2 *}$
}

\begin{abstract}
${ }^{1}$ Department of Pathology, ${ }^{2}$ Department of Obstetrics and Gynecology, National Health Insurance Service, Ilsan Hospital, Gyeonggido, South Korea
\end{abstract}

Received: 22 July 2018

Revised: 03 September 2018

Accepted: 06 September 2018

\author{
*Correspondence: \\ Dr. Jae Eun Chung, \\ E-mail: jiupark@naver.com
}

Copyright: (c) the author(s), publisher and licensee Medip Academy. This is an open-access article distributed under the terms of the Creative Commons Attribution Non-Commercial License, which permits unrestricted non-commercial use, distribution, and reproduction in any medium, provided the original work is properly cited.

\begin{abstract}
Sertoli-Leydig cell tumors (SLCTs) arise from the non-germ cell component of the ovary and typically present in young women with evidence of hyperandrogenism such as precocious puberty, amenorrhea, hirsutism and virilization. It is very rare accounting for less than $0.2 \%$ of all ovarian tumors, and because of the rarity, no standardized treatment approach has reached a consensus. The prognosis is generally good with complete reversion of symptoms after surgery, although some cases have been reported to be malignant. Recently the need for DICER1 mutations testing in paediatric patients has been emphasized for the surveillance of possible synchronous tumors and affected family members. Authors present here a case of Sertoli-Leydig cell tumor incidentally found while performing a hysterectomy with bilateral salpingo-oophorectomy in a postmenopausal woman with endometrial hyperplasia that caused intractable vaginal bleeding.
\end{abstract}

Keywords: Postmenopausal bleeding, Sertoli-Leydig cell tumor, Sex cord stromal tumor

\section{INTRODUCTION}

Sertoli-Leydig cell tumors (SLCTs) arise from the nongerm cell component of the ovary and belong to the group of sex-cord stromal tumors (SCSTs). ${ }^{1}$ The incidence of SLCTs is rather rare accounting for less than $0.2 \%$ of all ovarian tumors. ${ }^{2}$ Rather provoking clinical features such as abrupt onset of hypertrichosis, male type baldness, and deepening of voice in women may be presented in SLCTs. ${ }^{3}$ Typical cases of SLCTs with clinical signs of hyperandrogenism accompanied by the increased level of androgenic hormones such as testosterone should not be missed, rendering an early diagnosis and proper intervention with good prognosis possible. ${ }^{4}$ Asymptomatic Sertoli-Leydig cell tumors warrant special attention because without the clinical signs of abrupt onset of virilization it is rather difficult to be suspicious of the tumor due to the lack of accuracy in detecting it through radiologic studies. Authors hereby present a case of Sertoli-Leydig cell tumor without the clinical signs of hyperandrogenism that was incidentally found in a hysterectomy with bilateral salpingooophorectomy specimen, to emphasize the importance of the preventive bilateral salpingo-oophorectomy in postmenopausal women even with unremarkable intraoperative findings of the adnexa.

\section{CASE REPORT}

A 61-year-old postmenopausal women with abrupt onset of vaginal bleeding was examined. Her menstruation history was unremarkable, experiencing menarche at the age of 13 , having regular periods throughout, and hitting menopause at the age of 52. She denied taking neither menopausal hormone therapy nor dietary supplements such as evening-prim rose or black cocosh. She had 
given three spontaneous vaginal deliveries with no complications. For a duration of 15 years, she took 5 transvaginal ultrasonography exams in which an intramural leiomyoma measuring $4 * 4 \mathrm{~cm}$ was observed without any demonstrable size change. Bilateral adnexa were unremarkable as well as the endometrium. The ultrasonography taken in the presence of the abrupt vaginal bleeding revealed a thick endometrium measuring $15.8 \mathrm{~mm}$. Other than the endometrial pathology, the intramural leiomyoma showed no interval change and bilateral adnexa were unremarkable. A diagnostic dilatation and curettage was undertaken of which the result came out to be simple hyperplasia without atypia of the endometrium. The vaginal bleeding did not stop after the procedure for a full month, rendering hysterectomy as the treatment modality to control her continuous bleeding. A single port laparoscopic total hysterectomy with preventive bilateral salpingo-oophorectomy was performed. Entering the pelvic cavity, other than the intramural leiomyoma, intraoperative findings including bilateral adnexa were not remarkable. Bilateral salpingooophorectomy was done as it was the usual procedure to be taken for a postmenopausal woman undergoing hysterectomy (Figure 1).

As a routine measure in this institute, extraction of the specimen including the uterus and bilateral adnexa through the vagina was done after placing the specimen in a large size vinyl pouch to avoid any spillage in the pelvic cavity. The pathology report of her uterus revealed complex hyperplasia without atypia of the endometrium with an intramural leiomyoma. Her right ovary included a well differentiated $2 * 1 \mathrm{~cm}$ size Sertoli-Leydig cell tumor confined to the ovary which was only an incidental finding. Since the ovarian capsule was not ruptured, even without the lymph node dissection, this case was designated as stage 1A ovarian cancer rendering no need for postoperative chemotherapy. During the 5 year follow up period without any intervention, the patient is doing well with no symptoms and signs of tumor recurrence.

\section{DISCUSSION}

Sertoli-Leydig cell tumors (SLCTs) belong to the group of sex-cord stromal tumors (SCSTs) and account for less than $0.2 \%$ of all ovarian tumors. ${ }^{2}$ It is known to be presented with rather provoking clinical features such as abrupt onset of hypertrichosis, male type baldness, and deepening of voice in women. ${ }^{3}$ Patients showing clinical signs of hyperandrogenism accompany increased level of androgenic hormones such as testosterone, rendering an early diagnosis and proper intervention with good prognosis possible. ${ }^{4}$ Obesity, androgen producing adrenal tumors, congenital adrenal hyperplasia, and Cushing's syndrome are some of the disease entities that might also result in female hyperandrogenism. ${ }^{5}$ Although virilization is the key feature of suspecting the presence of SLCTs, other symptoms such as hyperestrogenism or abdominal pain and distention due to the sheer size of the mass also occur. ${ }^{6}$ In the study involving 11 SLCTs from a single institution, all of the cases presented with an adnexal mass varying from $5 \mathrm{~cm}$ to $20 \mathrm{~cm}^{7}$ Radiologic studies such as pelvic ultrasonography and computerized tomography (CT) are not the recommended definitive means of diagnosis due to is lack of accuracy in diagnosing the SLCTs. ${ }^{8}$ This is a unique case of an incidental SLCT where neither clinical symptom such as virilization nor radiologic findings such as adnexal mass were noted prior to the surgery. Sertoli cells are known to secrete estrogens resulting in hyperestrogenism, but it remains a question whether or not the endometrial hyperplasia in this case has resulted from hyperestrogenism released from the SLCT of the ovary. ${ }^{9}$ Unfortunately, the authors had no suspicion of SCLT prior to the surgery, thereby hormonal levels were not taken. In the absence of any hallmark signs of this rare tumor, incidental detection of it might come as a surprise, but should be treated accordingly. ${ }^{10}$

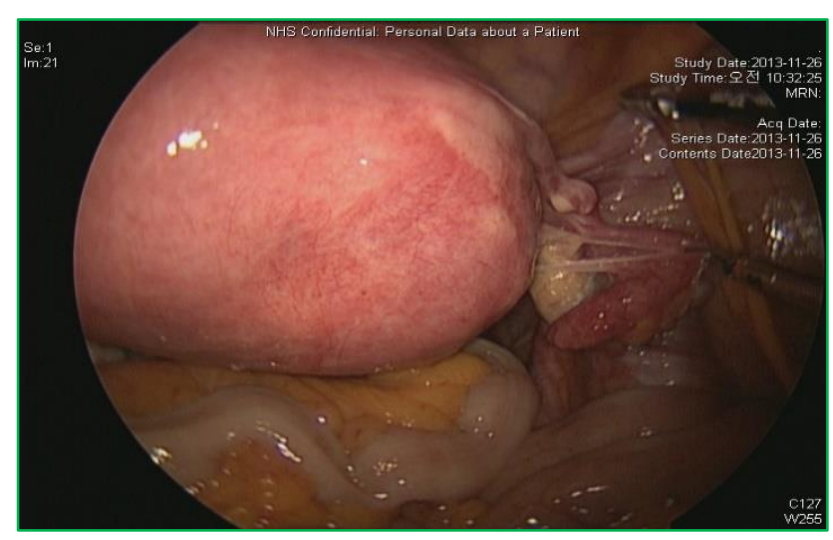

Figure 1: Intraoperative finding of the right adnexa, which was not remarkable.

Even with the unremarkable intraoperative finding of the right ovary, preventive salpingo-oophorectomy was done following the guideline as a preemptive procedure to be taken in postmenopausal hysterectomy cases (Figure 1). ${ }^{11}$

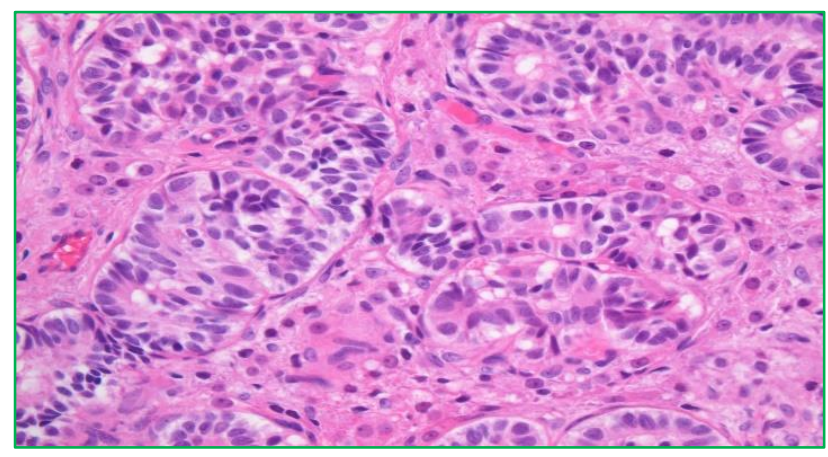

Figure 2: Histopathologic findings of the ovarian Sertoli-Leydig cell tumor $400 \mathrm{X}$-Sertoli cell tubules are surrounded by Leydig cells with pale granular cytoplasm.

Prophylactic bilateral salpingo-oophorectomy in postmenopausal women, and in the same context, 
prophylactic bilateral salpingectomy in premenopausal women has been recommended at the time of hysterectomy with benign conditions in order to reduce the risk of ovarian and fallopian tube cancer. ${ }^{12}$ SLCTs are included in the branch of SCSTs and are histologically divided into well-differentiated, moderatelydifferentiated, poorly-differentiated, retiform and mixed pattern. ${ }^{13}$ In this case, a well-differentiated SLCT with solid and hollow tubules composed of Sertoli cells and a delicate fibrous stroma containing Leydig cells with pale granular cytoplasm were noted (Figure 2). Calretinin is reported to be a specific immunohistochemical marker of SCSTs, therefore aiding in the differentiation of SCSTs from other malignancies. ${ }^{14}$ In this case, both Sertoli cells and Leydig cells showed positive signs of calretinin (Figure 3). In postmenopausal women with the symptoms and signs of hyperstrogenism, measuring the hormone levels and being suspicious of the possibility of hormone producing tumors, though rare, is advisable. Authors hereby present a case of Sertoli-Leydig cell tumor without the clinical signs of hyperandrogenism that was incidentally found in a hysterectomy with bilateral salpingo-oophorectomy specimen. Authors emphasize the importance of carrying out a preventive bilateral salpingo-oophorectomy in postmenopausal women undergoing hysterectomy for a benign pathology, even with unremarkable intraoperative findings of the adnexa.

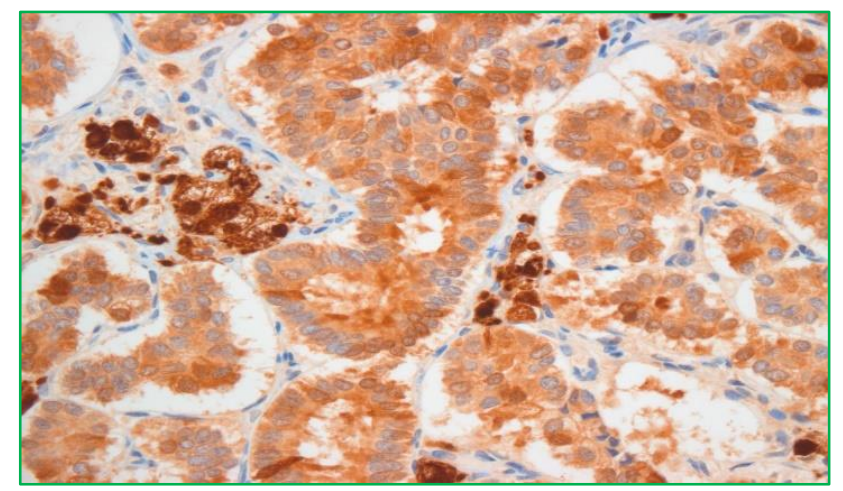

Figure 2: Histopathologic findings of the ovarian Sertoli-Leydig cell tumor 400X-Calretinin shows positive findings for Sertoli cells (bright) and Leydig cells (dark and granular).

Funding: No funding sources

Conflict of interest: None declared

Ethical approval: Not required

\section{REFERENCES}

1. Schultz KA, Harris AK, Schneider DT. Ovarian sex cord-stromal tumor. Oncol Pract. 2016;12:940.

2. Souto SB, Baptista PV, Braga DC. Ovarian Leydig cell tumor in a post-menopausal patient with severe hyperandrogenism. Arq Bras Endocrinol Metab. 2014;58:68-70.
3. Swain J, Sharma S, Prakash V. Steroid cell tumor: a rare cause of hirsutism in a female. Endocrinol Diabetes Metab Case Rep. 2013;2013:130030.

4. Luke AM, Moroney JW, Snitchler A, Whiteway SL. Ovarian Sertoli-Leydig cell tumor with elevated inhibin $\mathrm{B}$ as a cause of secondary amenorrhea in an adolescent with germ line DICER1 mutation. J Pediatr Adolesc Gynecol. 2017;30:598-600.

5. Koeneman MM, Heiligers-Duckers C, van der Velde R, Wouda S, Rooij MJM, Boskamp D. Ovarian Leydig cell hyperplasia as a rare cause of hair loss in a postmenopausal female patient: a case report and diagnostic approach toward postmenopausal hyperandrogenism. European J Obstet Reprod Biol. 2016;199:198-200.

6. Litta P, Saccardi C, Conte L, Codroma A, Angioni S, Mioni R. Sertoli-Leydig cell tumors: current status of surgical management: literature review and proposal of treatment. Gynecol Endocrinol. 2013;29:412-7.

7. Nam SM, Kim JW, Eoh KJ, Kim HM, Lee JY, Nam EJ, et al. A novel clinicopathological analysis of early stage ovarian Sertoli-Leydig cell tumors at a single institution. Obstet Gynecol Sci. 2017;60(1):39-45.

8. Palha A, Cortez L, Tavares AP, Agapito A. Leydig cell tumor and mature ovarian teratoma: rare androgensecreting ovarian tumors in postmenopausal women. BMJ Case Rep. 2016;2016:bcr2016215985.

9. Moghazy D, Sharan C, Nair M. Sertoli-Leydig cell tumor with unique nail findings in a postmenopausal woman: a case report and literature review. J Ovarian Res. 2014;7:83-7.

10. Shaw NM, Stauffer C, Eisenberg ML. Leydig cell tumor found incidentally during microscopic testicular sperm extraction in patient with mosaic Klinefelter syndrome: case report. Fertil Steril. 2016;106:1344-7.

11. Walker J, Powell B, Chen LM, Carter J, Bae Jump V, Gibb R, et al. Society of gynecologic oncology recommendations for the prevention of ovarian cancer. Cancer. 2015;121:2108-20.

12. Perez-Lopez F, Ceausu I, Depypere H, Kehoe S, Lambrinoudaki I, Rees M, et al. Interventions to reduce the risk of ovarian and fallopian tube cancer: a European menopause and andropause society position statement. Maturitas. 2017;100:86-91.

13. Chen L, Tunnell C, De Petris G. Sertoli-Leydig cell tumor with heterologous element: a case report and a review of the literature. Int $\mathbf{J}$ Clin Exp Pathol. 2014; 7:1176-81.

14. Zhao C, Vinh TN, McManus K, Dabbs D, Barner R, Vang R. Identification of the most sensitive and robuts immunohistochemical markers in different categories of ovarian sex cord-stromal tumors. Am J Surg Pathol. 2009;33:354-66.

Cite this article as: Kim Y, Lee IO, Chung JE. Incidental finding of a Sertoli-Leydig cell tumor in a postmenopausal woman with complex endometrial hyperplasia. Int J Reprod Contracept Obstet Gynecol 2018;7:4279-81. 